\title{
A New Model for Performance Measurement in the Nigerian Public Service
}

\author{
Lawal Bello Dogarawa \\ Department of Planning, Research \& Data Management Services \\ Nigerian Maritime Administration and Safety Agency \\ NMRDC Complex, Kiri-Kiri, Lagos, Nigeria \\ Tel: 234-809-924-4001; 234-803-701-6226Ｅ-mail: lbdogarawa@yahoo.com
}

Received: June 2, 2011

Accepted: August 2, 2011 Published: December 1, 2011

doi:10.5539/ijbm.v6n12p212

URL: http://dx.doi.org/10.5539/ijbm.v6n12p212

NB: The views expressed in this Paper are entirely those of the Author and do not necessarily reflect the official position of his employer

\begin{abstract}
Performance measurement in the Nigerian Public Service (NPS) is based on Annual Performance Evaluation Report (APER). The volatility of staff disposition in the NPS is to such an extent that Public Servants may work under more than two direct superiors in two or more departments within a year. This makes the APER system deficient and calls for another model that can suit any sporadic circumstance. This Paper therefore develops a new Public Service Performance Measurement Model (PSPM Model) which addresses chaotic staff disposition and provides continuous record of Public Servant's performance on a monthly basis. It is a simplified Performance Measurement System (PMS) which tasks the employee to report his monthly activities, identify key challenges and suggest ways to overcome them as well as prepare the next month's activities all of which are to be assessed by his direct superior. The Model is intended to enhance the productivity of Public Servants. However, the Model requires an automated system of operation so that all entries and submissions will be done using intranet. The Model can also be modified and adopted by private enterprises. But the Model should be used in a manner that only those who have a role in providing performance records and performance measurement can have access without the possibility to change anything once it is processed.
\end{abstract}

Keywords: Nigeria, Public service, Performance, APER form, PSPM model

\section{Introduction}

Government is run by circulars, memos, minutes, meetings and reports in order to provide services to society based on the provisions of Public Service Rules (PSR) and the Financial Regulations (FR). The PSR is the machinery through which Government seeks to implement the policies, projects and programmes it has articulated. On the other hand, the FR states how resources can be accessed in order to execute the policies, projects and programmes.

Public Service is a dynamic structure of government which operates based on Rules that are reviewed every five years in Nigeria so as to keep in tune with changing times, to serve the current needs of society and to provide for the future requirements of the people. Public Servants comprise of senior and junior staff. They also consist of executive and administrative cadres who are largely distinguished based on their educational qualifications, training, skills, ranks and the duties they discharge. Whereas the conduct of Public Servant is guided by the Public Service Procedures (PSP) or Scheme of Service (SoS), ideally, every Public Servant has a Schedule of Duty which is assigned to him on assumption of duty. This means that the performance of any Public Servant is measurable. It is measurable because the PSR contains clear terms of the employment contract concerning the rights and privileges of the Public Servant, what is expected of him and the measures he could take to address his challenges as well as measures which Government can take regarding his positive or negative conduct.

\section{The Problem}

The Nigerian Public Service (NPS) is generally perceived to be inefficient and ineffective. According to Lawal (2009) the Nigerian Public Service suffers setback largely because of low quality of management. This implies 
that in years past, the productivity of the NPS was high and it can be attributed to effective and efficient administration. It also supposes that performance of the NPS was being measured. It further suggests that the performance measurement centres on the aggregate; by reviewing the macro output without examining the micro performance of individual staff. But that may not be the case because, Chapter 5, Section 1, Rule 1 through Section 4, Rule 2 of the PSR requires biannual and annual progress and performance reports to be prepared by the immediate supervising officer in respect of each officer on probation and confirmed ones respectively. Evaluating officers usually complete a standardised form to prepare the Annual Performance Evaluation Report (APER). Whereas one year may not be too long to assess the performance of a staff, recent development in the Public Service whereby officers are redeployed indiscriminately through inter-departmental transfers and sometimes inter-Agency movements during the year obviously creates a big challenge. In a situation whereby an officer moves round more than two different schedules in different departments or he is directly supervised by more than two superiors in one year becomes difficult to get a fair performance measurement at the end of the year. This scenario pertinently calls for a better form of performance measurement that will not leave any gap even under sporadic circumstance.

\section{Objectives}

It is observed that articles written on performance measurement in the Nigerian public sector generally focus on public sector enterprises as it was the case of Esu and Inyang (2009). Such articles not only adopt business performance evaluation mechanisms to assess public sector enterprises without taking cognisance of the stakeholders' perception and the enterprise mandate as enshrined in the law which establishes them, they also don't address the issue of performance measurement in core public service. There is also an apparent challenge in the use of APER Form to review the performance of public officers that work under different supervisors during the period of performance measurement. In order to avoid the mistakes and bridge the gap, this article seeks to develop a new model for performance measurement which will address chaotic staff disposition and provide continuous record of Public Servant's performance on a monthly basis.

\section{Methodology}

This article uses descriptive analysis and observation methods to critically examine performance measurement criteria in the NPS. The article relies on the PSR, the APER Form, the National Productivity Order of Merit (NPOM) Award Form and the scenarios observed in the NPS setting in recent times. It attempts to design a simplified Performance Measurement System (PMS) which tasks the employee to report his monthly activities, identify key challenges and suggest ways to overcome them as well as prepare the next month's activities all of which is to be endorsed by his direct superior. The article therefore presents a Model which fits the dynamic environment and also captures the scope of public service activities. It is expected that the Model will be comprehensive in evaluating and improving the performance of Public Servants as well as assist in planning and sustaining enriched and dynamic Public Service globally.

\section{Literature Review}

Gberevbie (2010) describes the Federal Civil Service as an institution established for the implementation of policies of the Federal Government in its quest for the enhancement of the living standard of Nigerians in terms of quality social service delivery and infrastructure development. On the other hand, OHCSF (2010) describes the Civil Service as a body of man and woman employed to ensure that policies and programmes of any government at any particular time are carried out. It believes that the Civil Service as part of Government never dies. Because of its perpetual nature and the changing nature of constitutionally elected governments, it has to be endowed with specific peculiarities to enable it serve any government no matter the political leaning of that government. It also recognises the Civil Service as a dynamic organization which is constantly evolving new techniques to improve upon its past as well as to meet fresh challenges. Adegoroye (2006) suggests the use of e-government solutions and supporting service delivery with a strong finance, budget and audit system. Notwithstanding this opinion, the OHCSF (2010) asserts that the Civil Servant is expected to use his initiative and judgment wisely in deciding issues since these decisions generally affect the lives of the citizens.

Performance Management is defined as the process of setting performance expectations, monitoring progress, measuring results, and appraising and rewarding or correcting employee performance. On the other hand, performance appraisals are an evaluation of an employees work.

Shane (2010) defines performance measurement as a philosophy of continuous learning in which feedback is used to make ongoing adjustments to the course of an organisation in the pursuit of its vision. Aighewi (2010) also defines special performance appraisal as the systematic evaluation of the individual employee with respect to his or her job performance and the potential for development. Shane (2010) further asserts that a balanced performance measurement is a management system which assesses the effectiveness of an organisation's operations from financial, client satisfaction, quality of service and innovation/learning perspectives so as to 
enable proactive correction and to promote continuous improvement. He cautions that acceptance of a PMS involves a gradual process of change in organisational culture which can be achieved by describing what performance measurement is and what it is not and by explaining the roles and responsibilities required of employees in order to alleviate fears. He further suggests that implementation of PMS should begin on a pilot basis for a period of 3 to 6 months so as to demonstrate the value of performance measurement and to build the competencies of those who are to measure performance.

Esu and Inyang (2009) assert that performance is a multi-dimensional construct the measurement of which varies depending on a variety of factors with the desired performance linked to the vision of the organisation. They contend that whether discussed or written, there are standard ways of measuring performance and the philosophy behind the standard is to accept or reflect on the job performed by an employee. However, this Author believes that the philosophy of establishing standard for performance measurement cannot be limited to "accept or reflect" as contended by Esu and Inyang because even where performance is accepted, the measurement method should provide room for improvement and when performance is below standard, it is not enough just to "reflect" on it; rather, it should lead to reprimand, training, job rotation and other actions that will reverse the situation for the benefits of both the employee and the organisation.

Performance management system can help superiors in giving clear job descriptions to the staff because a clear job description will encourage the employee to lead to more work efficiency during employment time. Gilbert (2006) asserts that performance appraisal system is used for determining whether the job holder meets the standard set for performance, as a basis for review of corporate plans, as a basis for determining training needs and for reviewing job standards. Mills et al (2010) posit that performance measures are also used to compare the performance of different organisations, plants, departments, teams and individuals, and to assess employees. They observe that most PMS are used as a reporting mechanisms (e.g. financial reports) while other systems are employed for controlling performance of products, employees and other resources within an organisation (e.g. costing systems, staff appraisal and reward systems). It was in this wise that Egbule (2010) reports that the National Salaries, Income and Wages Commission (NSIWC) had identified the need to establish productivity evaluation mechanism in the public sector and to determine performance measurement mechanisms for each agency of Government. However, Paul (2010) concludes that motivating civil servants for performance, capacity development and reform is far being a straightforward issue and no blueprint can be devised. She notes that individual incentives are often low-powered in the public sector mainly because of the difficulty to find appropriate objective performance measures. Gilbert (2010) recalls that before 1974, Confidential Reporting System (CRS) was in use in the Nigerian Public Service where the appraisee was not allowed to know the assessment made of him. However, following the Udoji Report of 1974, the Open Reporting System (ORS) was introduced which by 1983 was further modified to introduced additional assessment factors.

Aighewi (2010) states that one of the problems of performance rating is when appraisal is done periodically instead of continuously by which assessors are quite often influenced by recent incidents because they have forgotten certain significant effective or ineffective behaviour in the past which was not recorded. Gilbert (2006) also notes that one of the causes of abuse of the appraisal system was the desire to give close friends and relations advantage over others in competitive promotion exercise thereby making the system lost its usefulness and cannot be depended upon for assessment of performance. He observes that people assessing subordinates by the use of APER Form awards marks so generously that no one in a given group of officers being considered for any reward or promotion, were found to have scored lower than 95 percent and in some cases, with candidates scoring 100 percent. This is what Aighewi (2010) criticises as assessors' erroneous thinking that all employees and all jobs should be assessed in exactly the same way using the same procedures. Gilbert (2006) then argues that such scores are practically impossible in an objective assessment; and, there is even no evidence anywhere to show for high performance and excellence in the public service. Solution Consult (2000) advices on the need to document all performance problems regularly on appropriate appraisal or progressive discipline forms and provide the employee with a copy immediately. It contends that when superiors tolerate an employee with a performance problem for months and then suddenly give him/her a negative evaluation and probably lead to termination of appointment, the employee may claim that the action was arbitrary or discriminatory and may be able to show that no opportunity for improvement was given which may even result into court action. It is thus very important to minimize exposure to employee litigation by developing a checklist of items that are necessary for the enforcement of fair, consistent and legally sound performance appraisal systems.

In order to curtail the excesses of assessors, the Federal Civil Service Commission (FCSC) in 1996 introduced examination to be done for only 30 minutes in order to evaluate officers to be considered for promotion. Consequently, promotion became based examination, APER and seniority which carry 70 percent, 20 percent and 10 percent respectively. However, the FCSC itself was accused of sacrificing the otherwise promising career of competent and high-performing officers on the altar of corruption which makes people lose confidence on the 
FCSC leading to low morale, lack of commitment, frustration and low productivity (Gilbert, 2010). This probably appropriately position observation by Mokoro (2003) that civil servants in Nigeria operate in a cumbersome atmosphere while in terms of performance appraisal, OHCSF (2007) notes that even though there were enough details in the present APER, too much emphasis was placed on character trails as against the quantum of the officer's output. This was why Solution Consult (2009) suggests that a review audit system to prevent manager bias or personal feelings from impacting on the appraisal should be established; after all, Aighewi (2010) concludes that appraisal of traits, deficiencies and abilities for promotion or punishment purposes alone is no longer in vogue.

\section{Existing Models of Performance Measurement}

In human resource management, performance measurement takes place because there is employment. Employment is a contract between two parties, one being the employer and the other being the employee. An employer is a person or organisation that hires people to perform work in exchange for compensation, which is usually money in the form of wages or a salary. On the other hand, an employee is an individual who was hired by an employer to do a specific job after an application and interview process results in his or her selection as an employee. The terms of an individual's employment are specified by an offer letter, an employment contract, or verbally. In workplaces represented by a union, the collective bargaining agreement covers most aspects of an employee's relationship with the workplace. In consequence, an employee barters his skills, knowledge, experience and contribution in exchange for compensation from an employer. Each employee therefore has a specific job to accomplish that is often defined by a job description.

An employee has a boss that he reports to and takes instructions from who is usually the immediate or direct superior. The employee has a duty post or office in which he accomplishes the job. The employer supplies the employee with the tools and equipment necessary to perform work such as a table, chair, computer, telephone, file cabinet and supplies.

The employer's level of power over the employees is dependent upon numerous factors, the most influential being the nature of the contractual relationship between the two. This relationship is affected by three significant factors namely: interests, control and motivation. It is responsibility of the employer to manage and balance these factors in a way that enables a harmonious and productive working relationship. It is also expected that the employee will receive frequent performance feedback from the employer, rewards and recognition, as well as reasonable benefits package. However, either an employee or employer may end the relationship at any time. The contract between the two parties specifies the responsibilities of each when ending the relationship and may include requirements such as notice periods, severance pay and security measures.

In the NPS, employment contract is between Government and the Public Servant where the latter is the employee of the former. Chapter 2, Section I, Rule II of the PSR provides that appointment into the Federal Civil Service (FCS) to grade levels 12 to 17 shall be made through advertisement where there is no eligible officer for promotion or confirmation while appointments to grade levels 07 to 10 shall be on the basis of annual competitive civil service entry examination for new entrants and officers from other scheduled service. Rule III in Section III of the same Chapter also states that there shall be probation of not more than two years for new appointments that will be confirmed after passing the prescribed examination for the post they occupy and a satisfactory performance measurement. Furthermore, Section IV, Rule I provides that contract appointment shall be offered, after advertisement, for a specific period to those who are age 50 and above with specialised skills or competence where pensionable and temporary staff are inadequate. Such a staff cannot be promoted except where there is no suitable pensionable officer available or where he possesses an exceptional qualifications and suitable experience (Section VII, Rule VIII). However, Public Servants are to be promoted after 2, 3 and 4 years for those on grade levels 06 and below, 07 to 14 and 15 to 17 respectively strictly on the basis of competitive merit from amongst all eligible candidates in recognisance of their records of performance, potentials, seniority and record of conduct as provided under Rule I of Section VII in Chapter 2 of the PSR.

Thus, we can see that everything has been set out in the PSR about employment process and employee progression. However, certain conducts like inefficiency, insubordination, immorality, embezzlement, lateness, absenteeism and similar misconducts are unacceptable in Public Service. Chapter 3, Section II, Rule I of the PSR states that inefficiency consist of a series of omission or incompetence, the cumulative effect of which shows that the officer is not capable of discharging efficiently the duties of the office he holds. Whereas inefficiency is enough ground for disengaging an employee, Rule II and III provides that superior officers should notify the subordinate concern about any shortcomings or fault observed, maintain record of such notices and ensure that warnings have been served on the employee on three different occasions before proceedings for his removal could commence. 
Meanwhile, there is no record of the conduct of Public Servant that carries more weight than the APER. Mustapha (2008) states that the APER Form was designed to provide a full record of an officer's work conduct and capabilities annually from whose suitability for promotion and training may be judged. But Echu (2010) observes that such is not the case in the NPS. He asserts that most promotions, appointments and job placements are based on political affiliation, ethnicity, religious inclination or the connection and reference of the appointee to the people that matter. He also states that most of those employees so promoted or appointed may not necessarily be competent on the job.

The APER Form is divided into parts 1 to 5 in which part one shows the personal records of the employee and part two contains the target set, key achievements, job description, training/course attended and the job performance. On the other hand, assessment of performance by the superior, evaluation of character traits, work habits and leadership performance are provided in part three. In parts four and five, the employee will sign after commenting on the assessment made of him by the superior and the superior will countersign respectively. However, Mustapha (2008) observes that poor objectivity, poor feedback to employees, fear of reprisals in the case of adverse reports being issued on subordinates and even poor knowledge of the role of performance appraisal as a tool of management by both workers and superiors are some of the challenges facing the effective use of the APER Form. He suggests that staff assessment should be done more than once in a year by direct superiors in order to measure outputs rather than just inputs. He adds that the assessment should generate training for improvement apart from promotion while rewards should be tied to performance or non-performance so as to propel staff to work harder and dissuade them from dysfunctional work ethics.

The National Productivity Order of Merit Award nomination form for individuals (IPF - 01) on the other hand has 16 listed attributes which are to be graded between " $\mathrm{A}$ " and " $\mathrm{D}$ " so as to provide assessment for the preceding three years. The 16 "performance attributes" includes expertise; job performance; dedications; hard work; initiative; creativity; honesty and reliability. Others are self-discipline; moral leadership; responsibility; punctuality; team work; contribution to community; contribution to organisation and human relations.

The individual productivity nomination for merit award also requires information to be provided in respect of any acclaimed break through and any impact such break through has made. Whereas the grade "A" represents "Excellent"; "B" stance for "Good"; "C" means "Average" and "D" signifies "Below average" performance. Nominations are to be made by the employer usually presented by the head of department of the employee attached with curriculum vitae and independent briefs on the nominee in question.

As objective and open as the form for nomination for the national productivity merit award looks, in a situation where performance of Public Servants is assessed once a year coupled with the juggling of staff through inter-departmental redeployments, nominations for national productivity merit award will remain questionable. It is in the light of many observed assessment deficiencies that a new Model for Performance Measurement in the Nigerian Public Sector is presented below.

\section{7: New Model for Performance Measurement in Public Service}

This section discusses the new Public Service Performance Measurement Model (PSPM Model) which has been developed in order to assess Public Servants on a continuous basis and create room for sustainable performance improvement. The Model puts the employee and his superior to task by providing constant role to both of them throughout any month they are working together. Both the employee and his assessor are required to fill in their name, staff number, rank, unit/departments, location and the month for the report. After the common role, the Model is divided into two columns with the left hand side assigned to the employee and the right hand side assigned to the direct superior officer who will assess the employee for the month.

\subsection{Employee Column}

The employee's column consists of 11 elements which are to be tackled by the employee himself based on his duty and the activities he carried out during the month under review. One of the elements, the Schedule of Duty, is a recurring matter in the employee's work life until he is redeployed. The schedule of duty is given by the employer which is the basis of the employment contract and the superior officer is to ensure that the duty is carried out as specified. The employee is therefore to reproduce his schedule of duty every month when preparing his report.

The second element is about the tasks drawn out in order to carry out the job function. The element requires the employee to set target for himself which will be achieved in one month.

The third element requires the employee to outline his key achievements of the tasks he set for himself. This means that before even the superior give his assessment of the performance for the month, the employee can attest to himself how well he has performed. 
Since the employee is not working for himself, there must be a way to inform his superior about how the job is going on. The fourth element therefore requires the employee to prepare weekly report and submit to his direct superior. The employee may have served in a committee or has attended meetings or perhaps went on enforcement. Whatever activity went on, they employee is expected to submit a report which he should indicate in the performance measure sheet.

Aside from the routine activities, employees may be given special assignments such as impromptu relief duty, membership of an ad hoc committee or a directive to represent his superior at an event. There may also be a sudden change in the work environment which requires prompt attention by superiors. The employee is expected to submit a situational report. This is the fifth element under the employee's column.

The sixth element is the executive summary which the employee prepares in form of monthly report. The monthly report is very important to the head of unit because it forms the basis for his own Unit report which is an input into the departmental report that goes to the chief executive.

In view of the fact that there are challenges whether the employee achieves his target or not, the seventh element provides that the employee lists his challenges during the month. Related to the challenges are the ways they could be addressed which if the employee is allowed to recommend may enabled management to make informed decisions. Thus, the eighth element under the employee's column is about the proposed solutions to the challenges faced during the month which if considered may lead to improved performance by the employee.

The ninth element is to list those special duties which the employee carried out during the month. This is necessary despite the fact he has written situational report which he reported under the fifth element during the month. Ahead of the coming month, the employee is encouraged to prepare the tasks he wishes to execute in the course of doing his job. This is what constitutes the tenth element. The employee is recognised to be in the best position to articulate new tasks which if he accomplishes will increase his productivity having addressed the challenges faced in the preceding month.

Similar to schedule of duty which is given by the employer, the employee is expected to conduct himself in a manner that shows good personal traits. Five key attributes makes up the eleventh element under the employee's column. Although performance evaluation generally seeks for increase in productivity regardless of how it is achieved, it is meaningful to assess employee's punctuality, honesty, loyalty, reliability as well as his leadership potentials in order to determine the extent to which additional responsibility can be given to him.

\subsection{Assessor Column}

The immediate superior officer is required to assess the subordinate in 10 out of the 11 elements. He is however to confirm if the schedule of duty claimed by the subordinate under the first element is correct. This is because in the NPS there are workers who cross-carpet from their own schedule to hijack the duties of other officers. The superior officer should be in the position to attest to the claim of the schedule of duty which led to the tasks carried out by the employee and the various reports submitted.

The direct superior will grade the subordinate in the range between 4 and 1 where 4 is the highest grade and 1 being the lowest. In the case of the second element in which the subordinate outlines the tasks to be accomplished toward executing the schedule of duty, the role of the direct superior is to examine how relevant those tasks are to the schedule of duty.

The assessor will then evaluate the key achievements claimed by subordinate under the third element in order to state the level of compliance to the tasks already outlined in the second element. The superior will also state the timeliness of weekly reports submitted by the subordinate and how prompt he sends in situational reports as required under the fourth and fifth elements as well as the timeliness of monthly report under the sixth element.

Direct superior also has the responsibility to review the relevance of the challenges which the subordinate claimed have hindered him from higher performance and the solutions he proposes to address those constraints under the seventh and eighth elements. Despite the fact that the last item in any public service schedule of duty is "any other duty that may be assigned", it is imperative to distinguish between personal errands of the boss from special official assignments. Consequently, the significance of the special duties carried out by subordinate during the month should match the overall objectives of the organisation. The superior must therefore ensure that activities of the subordinate outside his schedule of duty which may be reported under ninth element are not for personal aggrandisement of a higher officer.

The superior will consider the challenges and solutions recommended to examine the relevance or otherwise of the new tasks set by the subordinate under the tenth element. The tasks for the month ahead must obviously also be relevant to the employee's schedule of duty. Whereas employee assessment from the second to the tenth elements may be relatively quantitative through review of work done in the month, the eleventh element is more-or-less qualitative and therefore a little difficult. The assessor is required to be highly objective by 
removing sentiments in grading the employee's honesty, loyalty and reliability. These personality traits actually depend on individual and must be seen from that perspective by direct superior each time an employee is assessed.

\subsection{Feedback}

The assessor has the responsibility of giving the average grade scored by the employee. To arrive at the average grade each score obtained by the employee will be added and divided by the total number of items contained from the second to the eleventh elements in the PSPM Model. An average grade of 3.6 to 4.0 represents "excellent"; 3.1 to 3.5 represents "very good"; 2.6 to 3.0 represents "good"; 2.1 to 2.5 represents "average"; 1.0 to 2.0 represents "below average". Thus, the monthly average grading system openly allows the employee to know the assessment of his performance for each month. At the end of the year, the monthly averages will be summed up and divided by 12 to get the annual average grade which is a fair representation of the employee's performance for the year in question. This is unlike the APER system, an annual event which is used for taking decision whether to promote the employee or not with performance assessment feedback coming 12 months after the work done. The practice obviously does not challenge the employee to improve on his performance so that it can have an immediate impact on the subsequent assessments.

The PSPM Model also provides that whilst the report is to be sent to the Administration and Personnel Services (APS) Department, copies will also be provided to the SERVICOM Unit of the organisation and the employee concerned. The essence of sending a copy to the SERVICOM Unit is to enable the Unit to examine the extent to which the worker is adhering to the service delivery charter the employee has signed. It will also assist the Unit to compare the individual worker's performance with stakeholders' feedback on the service they received from the employee concerned.

\section{Conclusion}

The PSPM Model can be introduced in public sector organisations on departmental basis or entirely into the organisation at once. It is designed to make Public Service appraisal more open the outcome of which can be determined by the Public Servant himself. However, the Model requires an automated system of operation so that all entries and submissions will be done using intranet. The Model can be adopted by limiting access to all those who have a role to play and without provision to change anything once it is processed.

\section{References}

Adegoroye, G. (2006). Reforming the Public Service in Nigeria: The Challenge of Improving Service Delivery. [Online] Available: www.bpsr.gov.ng/cnt/publications/Co

Akindele, S. T, Olaopa, O. R., and Obiyan, A. S. (2007). Fiscal Federalism and Local Government Finance in Nigeria: An Examination of Revenue Rights and Fiscal Jurisdiction. International Review of Administrative Sciences. [Online] Available: www.ras.sagepub.com/../557.abstract

Chinedu Arizona-Ogwu, I. (2010). "Civil Service Reform In Nigeria": The British Example! [Online] Available: www.nigeriansinamerica.com/articles

Echu, E. S. (2008). Motivation in Public Sector - The Nigerian Experience. [Online] Available: www.dspace.unijos.edu.ng/bitstream/1048

Elisabeth Paul. (2010). Motivating Civil Servants for Reform and Performance; UNDP Global Event Working Paper. [Online] Available: www.capacityisdevelopment.org/doccs

Fred-Adegbulugbe, C. (2010). Government cannot do much about productivity in public service. International Journal of Business and Management. [Online] Available: www.ccsenet.org/../1135

Gberevbei, D. E. (2010). Strategies for Employee Recruitment, Retention and Performance - Dimension of the Federal Civil Service of Nigeria. African Journal of Business Management, Vol. 4, No. 8. [Online] Available: www.academicsjournal.org/AJBM

Gilbert Ugbebor. (2006). Staff Performance Appraisal in the Public Service. [Online] Available: www.victoria.ac.nz/commonwealthsemi

Houseman, S. N. (1999). A Report on Temporary Help, On-Call, Direct-Hire Temporary, Leased, Contract Company, and Independent Contractor Employment in the United States; [Online] Available: www.dol.gov/../9.1_contractors.htm

Mukoro (2003). The Impact of Rules and Regulations on Personnel Performance in the Unified Local Government Service of Nigeria. Journal of Social Science, Vol. 7, No. 2. [Online] Available: www.krepublishers.com/02-Journals/J

Mustapha I. M. (2008). Manual and Questions \& Answers on Public Service Rules, Office Procedures, Office 
Routine and Reforms. Busco Publishing Academy, Lagos.

OHCSF (2007). Workshop on the Annual Performance and Evaluation Report; Appointment. [Online] Available: www.ohcsf.gov.ng/HOSFTestData/manua

Performance - Politics. [Online] Available: www.h-net.org/announce/show.cgi

Performance Appraisal in public service. [Online] Available: www.ohcsf.gov.ng/HOSFTestData/manua.

Performance in the Nigerian Public Service. [Online] Available: www.unn.edu.ng/home/index.php/View-.

Performance measurement. [Online] Available: www.allfreeessays.com/../90

Public Service Commission. (2010). Appointment, Promotion and Discipline in the Public Sector", being Paper delivered at Abuja during a Conference for Civil Servants in the Federal Civil Service.

Robert Dibie. (undated). Local Government Public Servants Performance and Citizens Participation in Governance in Nigeria. [Online] Available: www.questia.com/googleScholar.qst

Solutions Consultant and BizMantra. (2009). Tips for Performance Appraisal

Ushie, E. U., Ering, S. O., and Ingwu, E. U. (2000). Rationalisation in the Nigerian Public Service - Implications for Cross River State Worker Morale and Productivity. Journal of Business in Developing Nations.

[Online] Available: www.abujanigeria.academia.edu/UKERTORMO.

[Online] Available: www.academicjournals.org/ajbm/pdf/p,

[Online] Available: www.en.wikipedia.org/wiki/Employment

[Online] Available: www.hosf.gov.ng/node/333

[Online] Available: www.humanresources.about.com/od/glossar.

[Online] Available: www.nigeria.smetoolkit.org/nigeria/en/c

\section{A New Model for Performance Measurement in the Nigerian Public Service}

Name of Staff:

ID No:

Rank:

Unit:

Location:

Report for the Month of:
Name of Supervisor:

ID No:

Rank:

Dept:

Location: 
Table 1. Public Service Performance Measurement (PSPM) Model

\begin{tabular}{|c|c|c|c|c|}
\hline \multirow{2}{*}{$\begin{array}{l}\text { Staff Report } \\
\text { Schedule of Duty }\end{array}$} & \multicolumn{4}{|c|}{ Supervisor's Report on the Staff } \\
\hline & \multicolumn{4}{|c|}{ Confirmation of Schedule of Duty } \\
\hline \multirow[b]{2}{*}{$\begin{array}{l}1 . \\
2 . \\
3 . \\
4 . \\
5 . \\
6 . \\
7 . \\
8 . \\
9 .\end{array}$} & \multicolumn{2}{|c|}{ Correct } & \multicolumn{2}{|c|}{ Not Correct } \\
\hline & & & & \\
\hline \multirow[t]{3}{*}{ Tasks for the Month } & \multicolumn{4}{|c|}{ Relevance of Tasks to Schedule of Duty } \\
\hline & $\begin{array}{c}\text { Very Relevant } \\
\text { (4) } \\
\end{array}$ & $\begin{array}{l}\text { Relevant } \\
\text { (3) }\end{array}$ & $\begin{array}{l}\text { Slightly } \\
\text { (2) }\end{array}$ & $\begin{array}{c}\text { Not Relevant } \\
\text { (1) }\end{array}$ \\
\hline & & & & \\
\hline Details of Tasks Achievement & \multicolumn{4}{|c|}{ Level of Compliance to Tasks } \\
\hline \multirow[b]{2}{*}{$\begin{array}{l}1 . \\
2 . \\
3 . \\
4 . \\
5 . \\
6 . \\
7 . \\
8 . \\
9 .\end{array}$} & $\begin{array}{c}\text { V/Strong } \\
(4)\end{array}$ & $\begin{array}{l}\text { Strong } \\
(3)\end{array}$ & $\begin{array}{l}\text { Average } \\
(2)\end{array}$ & $\begin{array}{l}\text { Weak } \\
(1)\end{array}$ \\
\hline & & & & \\
\hline \multirow[t]{2}{*}{ Weekly Report Submitted } & \multicolumn{4}{|c|}{ Timeliness of Submission of Reports } \\
\hline & $\begin{array}{l}\text { Very Timely } \\
\quad(4)\end{array}$ & $\begin{array}{l}\text { Timely } \\
\text { (3) }\end{array}$ & $\begin{array}{l}\text { Late } \\
(2)\end{array}$ & $\begin{array}{l}\text { Very Late } \\
\text { (1) }\end{array}$ \\
\hline $\begin{array}{l}\text { Week } 1 \\
\text { Week } 2 \\
\text { Week } 3 \\
\text { Week } 4\end{array}$ & & & & \\
\hline \multirow[t]{3}{*}{ Situational Reports Submitted } & \multicolumn{4}{|c|}{ Promptness of Report } \\
\hline & $\begin{array}{l}\text { Very Prompt } \\
\quad(4)\end{array}$ & $\begin{array}{l}\text { Promptly } \\
\text { (3) }\end{array}$ & $\begin{array}{l}\text { Late } \\
(2)\end{array}$ & $\begin{array}{l}\text { Belated } \\
(1)\end{array}$ \\
\hline & & & & \\
\hline \multirow[t]{2}{*}{ Monthly Report Submitted } & \multicolumn{4}{|c|}{ Timeliness of Submission of Monthly Report } \\
\hline & $\begin{array}{c}\text { Very Timely } \\
(4)\end{array}$ & $\begin{array}{l}\text { Timely } \\
\text { (3) }\end{array}$ & $\begin{array}{l}\text { Late } \\
(2)\end{array}$ & $\begin{array}{l}\text { Very Late } \\
\text { (1) }\end{array}$ \\
\hline
\end{tabular}




\begin{tabular}{|c|c|c|c|c|}
\hline \multirow[t]{3}{*}{ Challenges in the Month } & \multicolumn{4}{|c|}{ Relevance of Challenges to Tasks } \\
\hline & $\begin{array}{c}\text { Very/Relevant } \\
\text { (4) }\end{array}$ & $\begin{array}{l}\text { Relevant } \\
\text { (3) }\end{array}$ & $\begin{array}{l}\text { Slightly } \\
(2)\end{array}$ & $\begin{array}{c}\text { Not Relevant } \\
\text { (1) }\end{array}$ \\
\hline & & & & \\
\hline Proposed Solutions to Challenges & \multicolumn{4}{|c|}{ Relevance of Solutions to Challenges } \\
\hline \multirow{2}{*}{$\begin{array}{l} \\
1 . \\
2 . \\
3 . \\
4 . \\
5 . \\
5 .\end{array}$} & $\begin{array}{c}\text { Very Relevant } \\
(4)\end{array}$ & $\begin{array}{c}\text { Relevant } \\
(3)\end{array}$ & $\begin{array}{l}\text { Slightly } \\
(2)\end{array}$ & $\begin{array}{c}\text { Not Relevant } \\
\text { (1) }\end{array}$ \\
\hline & & & & \\
\hline \multirow{3}{*}{$\begin{array}{l}\text { Special Duties Carried Out in the } \\
\text { Month }\end{array}$} & \multicolumn{4}{|c|}{ Significance to Overall Obj. of the Organisation } \\
\hline & $\begin{array}{l}\text { Very } \\
(4)\end{array}$ & $\begin{array}{c}\text { Significant } \\
\text { (3) }\end{array}$ & $\begin{array}{l}\text { Slightly } \\
\text { (2) }\end{array}$ & $\begin{array}{c}\text { Not Significant } \\
\text { (1) }\end{array}$ \\
\hline & & & & \\
\hline \multirow[t]{3}{*}{ Next Month's Tasks } & \multicolumn{4}{|c|}{ Relevance of New Tasks to Schedule of Duty } \\
\hline & $\begin{array}{l}\text { Very Relevant } \\
\text { (4) }\end{array}$ & $\begin{array}{c}\text { Relevant } \\
\text { (3) }\end{array}$ & $\begin{array}{l}\text { Slightly } \\
(2)\end{array}$ & $\begin{array}{c}\text { Not Relevant } \\
\text { (1) }\end{array}$ \\
\hline & & & & \\
\hline \multirow[t]{2}{*}{ General Comments } & \multicolumn{4}{|c|}{ Comments by Supervisor } \\
\hline & $\begin{array}{c}\text { Excellent } \\
(4)\end{array}$ & $\begin{array}{c}\text { Good } \\
\text { (3) }\end{array}$ & $\begin{array}{c}\text { Average } \\
(2)\end{array}$ & $\begin{array}{c}\text { Below Average } \\
\text { (1) }\end{array}$ \\
\hline \multirow{3}{*}{$\begin{array}{l}\text { Personality Traits } \\
\text { 1. Punctuality } \\
\text { 2. Honesty } \\
\text { 3. Loyalty } \\
\text { 4. Reliability } \\
\text { 5. Leadership } \\
\text { Feedback } \\
\text { Average grade }\end{array}$} & & & & \\
\hline & \multicolumn{4}{|l|}{ This month grade: } \\
\hline & $\begin{array}{l}\square \text { Personnel Dept } \\
\square \text { Employee }\end{array}$ & $\square \mathrm{SER}$ & COM Unit & \\
\hline
\end{tabular}

